\title{
Where does work belong anymore? The implications of intensive homebased working
}

Purpose: The purpose of this 'thought piece' is to consider the everyday realities of homebased working and the implications for work during a global pandemic and beyond.

Approach: We present a conceptual framework for considering the domestic sphere as a social space and apply this framework to consider the existing evidence base on homebased working. In particular, we consider the implications of homebased working during and after the COVID-19 pandemic in terms of gender.

Findings: We identify key challenges in relation to flexibility, work intensification and socioeconomic differences. Consideration of these areas highlights the potential pitfalls and challenges that are likely to persist as many organisations begin to plan for an increase in homebased working.

Originality: We argue that some commentators have been too quick to celebrate the apparent successes of the sudden, unplanned move to intensive homebased working. Important differences in occupation, gender and other socio-economic factors will have important implications for the experience of homebased working for many workers and their co-residents.

Keywords: Homebased working, telework, work-life balance, COVID-19

The COVID-19 pandemic has led to an unprecedented shift towards full-time homebased work across all socio-economic groups. This is a sudden and rapid acceleration of a longer- 
term trend. For example, in the EU 5.4\% of those employed 'usually' work from home, a figure that has remained consistent in recent years. However, those who 'sometimes' work from home has risen from 6\% in 2009 to 9\% in 2019 (European Commission, 2020). Now, through a rapid set of changes, we have between 30 and $40 \%$ of those who were actively engaged in the labour market immediately pre-COVID, working from home. Commentators in the press (e.g. Guardian, 2020a) were quick to suggest that the Coronavirus outbreak might 'offer an opportunity for many companies to finally build a culture that allows long-overdue work flexibility' and that 'many employees for companies who have sent all staff home are already starting to question why they had to go into the office in the first place'. We however, believe that such proclamations should be evaluated more cautiously.

With declarations of the success of the COVID-19 homeworking 'experiment' by many organisations, including giants such as Twitter and Facebook, and their subsequent plans to make homebased working the norm rather than the exception, it seems likely that this homeworking experiment maybe here to stay (Bartik et al., 2020). It is inevitable that such radical changes to the organisation of work will impact the future relationship between the labour process and the domestic sphere. This has very immediate impacts on the lives of those currently operating from their kitchens, living rooms and spare bedrooms. However, discussions have tended to focus on ICT and productivity gains, often obscuring important differential impacts resulting from occupation, gender and other socio-economic factors

Drawing on a conception of social space as a '(social) product' (Lefebvre, 1991: 26), this 'thought piece' explores some of the key points of tension that result from the contested nature of home-work spaces. After setting out a conception of social space for understanding homebased working, we discuss some of the potential challenges relating to flexibility, work 
intensification and socio-economic differences. We conclude by suggesting the importance of engaging critically and comprehensively with the realities of homebased working.

\section{Theorising the domestic sphere}

ICT has enabled many of us to work in new ways from home, facilitating our file-share collaborations and Zoom marathons. However, the relative ease of homebased teleworking, accelerated by the lockdown and social distancing measures necessitated by COVID-19, should not create the false impression that places are interchangeable (Halford, 2005). It is not simply that paid work has been relocated but that its repositioning within the home has, for many, intensified as a result of the pandemic. Homebased working involves more than the loss of interminable commutes, the (in)effectiveness of video conferencing technology or who should pay for our increased electricity bills. Here, we seek to critically explore the domestic sphere of the home as a site for paid work.

The importance of extending our understanding of space is in moving beyond a simplistic 'Euclidean' conception of an empty container to be filled with a variety of activities in different measures. Instead, we follow Henri Lefebvre (1991: 26) in arguing that the home is a social space and that '(social) space is a (social) product'. Lefebvre's conception of space as dynamic, dialectical and full of meaning(s) has been hugely influential. For our purposes, such an understanding highlights the contested nature of home-work spaces and moves us closer to an appreciation of the social implications of a fluid, multi-faceted spatial construct (Wapshott and Mallett, 2012).

The ways in which spaces are 'lived in', involve not only practical activities but also the user's symbolic understanding and imagination. The home has long been recognised as a contested 
space, imbued with the potential for exertions of power and resistance. The domestic space is not a neutral one, for example as a result of 'the association of women with reproductive labour, and the privatization of this within the home' (Dale, 2014: 122). Sustained support for traditional gender roles is a primary example of unequal power dynamics that leave women undertaking disproportionately more housework and caring roles. Munro and Madigan (1999) emphasise women's traditional responsibility for 'domestic order' and the creation and maintenance of social space within the home. This can result in the ways in which 'Many women are constantly on duty [... and] subsume their own relaxation to fostering it in other[s]' (p.116).

As we discuss below, this gendered aspect of the domestic space has important implications in terms of the effects of homebased working during the COVID-19 pandemic, especially for working mothers. Without childcare, schools, social networks and other forms of support external to a household, unpaid care work and housework dramatically increased during the lockdown. Initial research suggests that this work was unequally distributed, burdening women more than men. For example, according to the UK Official for National Statistics, a higher proportion of women than men report having to change the way that they work as a result of the coronavirus pandemic (ONS, 2020).

An understanding of social space must also be attentive to the influence of socio-economic factors. For many, homebased working involves inhabiting 'hybrid' workspaces. Not everyone has the luxury of a room dedicated to homebased working or, even where there is an available spare room - other blurring of work and non-work spaces and time may still occur (Halford, 2005). We are thus developing an argument to identify the potential complexities of 
homebased working that must be taken into account when considering the realities of the lives of those engaged in of homebased working.

\section{The future of flexible working?}

Optimistic studies focus on homebased work's emancipatory potential. It is claimed to offer greater flexibility (Sullivan and Smithson, 2007); to enable workers to achieve work-life balance (WLB) by making it easier to juggle work and family responsibilities with no commute and more time for family and leisure (Powell and Craig, 2015). There is evidence that lends support to the benefits of homebased working for both organisations and individuals.

Studies have highlighted that work-life balance in homeworking is a learning process, where the first weeks or months are an adjustment period, until the homeworkers' experience eventually improves (Maruyama, Hopkinson and James, 2009). A study by Beauregard, Basile and Canoico (2013) suggests that $75 \%$ of homeworkers believe that their productivity is higher at home than in the office. Redman, Snape and Ashurst (2009) studied professional and managerial workers and found, for example, that hours worked in the home was positively associated with job and life satisfaction and negatively associated with burnout and stress. They conclude that: 'the greater flexibility afforded by working at home helps prevent family responsibilities interfering with work' (p.178). However, they add that 'it does not prevent work responsibilities interfering with family life' (ibid). It is in this way that differential impacts from work intensification through enforced homebased working may manifest.

Under COVID-19 measures in the UK, where many homes have become multi-occupational, multi-person workplaces and schools, there is not only challenges of boundaries but also conceptions of the domestic sphere. The sense of control implicit in notions of flexibility may 
itself be illusory: policies and practices can obscure persistent rules, prohibitions and other means of control derived from organizational and societal norms and expectations (Lewis, Gambles and Rapoport, 2007). In response to increasing tensions between work and family schedules (van der Lippe and Lippényi, 2018), new rules emerge to manage contestation.

Territory within the home is marked out, not only in terms of physical spaces but, as Munro and Madigan (1999: 113) emphasise, through 'time zoning (rather than space zoning)'. Time periods become compartmentalised in the search for personal space or time for oneself. In this way, what may at first appear as an opportunity for flexibility, can evolve to generate a new set of constraints as one negotiates with fellow residents, co-workers and clients. O'Neil et al. (2009) succinctly note that telework may be a double-edged sword, as it promotes work flexibility but simultaneously tends to increase working hours, making it difficult to determine the impact on work-life balance and relationships with family and other co-residents'. Under COVID-19 measures, time for oneself might also need be replaced with time for increased unpaid care and housework. It might also be excessive, leading to feelings of loneliness, which may be then driving homeworkers to work excessively due to a lack of opportunities to socialise.

Employee productivity expectations most often remain separated from considerations of an employee's private life. Despite progress in homebased work adoption, the division between work and private life, where staff are expected to choose amongst priorities (e.g. career/high productivity or children), remains widespread (Bailyn 2006). As we discuss below, the COVID19 working arrangements showcase an extreme challenge of separating the private from the public or work sphere. 
It is useful to differentiate homebased working from other forms of telework that may be less exclusively focused on the home. The dominant mode of working that has emerged for many as a result of lockdown corresponds with what Sullivan (2003) defined as 'telehomeworking'. For us, it is the home that is the particularly salient element here. The focus of work exclusively or predominantly within the home is likely to be a very different experience to that of the 'digital nomad' working across coffee shops, public transport or at the gym. It may heighten some of the challenges and potential dangers already inherent in homebased working.

Notwithstanding the potential for increasing economic participation through homebased work, concerns remain about the exploitation of those with caring responsibilities. When we are at home it can be difficult (at times impossible) to leave behind domestic tasks, especially where those 'tasks' need care or help with their home schooling. Perhaps it is therefore unsurprising that homebased working increases the proportion of time women (most often) spend on housework and childcare, reproducing and reinforcing gender roles within the new 'work-space' (Chung and Van der Lippe, 2018). Consequently, homebased working has the potential to 'reinforce the domestic burden of women and perpetuate the marginalization of female employment' (Sullivan, and Lewis, 2001: 125).

Sullivan and Lewis cite the classic study of the relationship between teleworking and gender by Huws et al. (1990). When looking at homebased working, Huws and colleagues found that men (and some highly successful women) benefit from having separate space (a home office) and gatekeepers to protect their working environment. The affordance of a dedicated space can be distinguished from the majority of homebased women workers who struggle to draw a clear line between home and work. Early data on homebased working during the first month 
of lockdown reveal the huge pressures on working parents during this period. It also suggests that mothers are spending less time on paid work and more on household responsibilities and are more frequently interrupted by childcare tasks (Andrew et al., 2020; see also Alon, Doepke, Olmstead-Rumsey and Tertilt, 2020).

This sense of a boundary between home and work is important but should never be conceived as straightforwardly an impermeable barrier in social space. The potential implications of homebased working go beyond the demarcation of space within the home. For some workers, going to the workplace is associated with achievement, relaxation, friendship and an escape from domestic chores (Maruyama, Hopkinson and James, 2009). To date, there has been insufficient consideration of the potential losses of these benefits. It is unsurprising that people's well-being is affected by working at home amidst a global pandemic. For example, in July 2020, UK respondents to an ONS survey reported that they were feeling bored (around $50 \%)$, with some feeling lonely (34\%) and others reporting that they were spending too much time with household members (22\%). However, only $16 \%$ reported finding working from home difficult (ONS, 2020). Nonetheless, if the higher rates of homebased working persist, the longer term effects on well-being will need to be closely monitored.

As hinted at by the responses to the ONS study reported above, the effects of locating work in the home also extend beyond the homeworker to co-residents, often creating tensions (Fitzgerald and Winter, 2001). Studies have suggested 'battles' (Tietze and Musson, 2005) occur over space in the home when work tasks must be accommodated within the living space. Homebased working can cause co-residents to experience impositions such as having to moderate their noise during working periods and other challenges to their everyday domestic behaviour (Sullivan, 2000). Vitters $\varnothing$ et al. (2003) found that those working from 
home for a significant proportion of their working time, had reduced general satisfaction with their partner. This may be heightened where co-residents are conducting their own homebased work or schoolwork.

The tensions created with co-residents may be a result of homeworkers distancing themselves from their families related to overwork, bringing problems from work into family life, unclear boundaries or unevenly distributed domestic work and chores between partners. Tietze and Musson (2003: 450) quote a worker who explained that, during the working day, he treated his children in a business-like manner: 'When I have to go downstairs, I treat the children professionally, that means courteously, but briefly'. In the current scenario, where homebased working is prolonged and intensive, stress and tensions may be further heightened. Yet, the experiences of, and on, co-residents remain largely ignored (Sullivan, and Lewis, 2001; Wapshott and Mallett, 2012).

Alongside acts of resilience, affection and solidarity, staying at home for a long period increases the dangers of social isolation (Cooper and Kurland, 2002), incidents of domestic violence as well as divorce rates, as the experience of locked-down countries across the world has taught us (Guardian 2020b, 2020c). By association, the economic downturn associated with lockdown is likely to cause anxiety over lost income and the prospects of future unemployment only a decade after a major recession (Blanchflower, 2019) and fuelled by social distancing and the very real, immediate possibility of employment insecurity (IES Wellbeing Survey, 2020). Again, there are differences between genders, for example, within opposite sex parental couples, it is mothers who are more likely to have quit work, lost their job or been furloughed (Andrew et al., 2020).

\section{Socio-economic differences}


It is widely recognised that 'The COVID-19 pandemic has [...] forcefully pushed societal inequalities into public consciousness' (Bapuji, Patel, Ertug and Allen, 2020: 2). We should be wary of any conceptualisation of homebased work or understandings of how households manage the impact of lockdown or similar social distancing measures that omits an assessment of socio-economic inequalities. Not all households reside in large, detached homes with spare bedrooms, ample gardens or nearby, accessible public spaces. Household overcrowding indicates material deprivation acting as a proxy measure for socioeconomic status (Cable and Sacker, 2019) and factors such as broadband access and home computing facilities will have a bearing on the effectiveness and wider implications of homebased working. Space is key to both the practical and psychological impact of homeworking, especially in conjunction with the COVID-19 management measures, such as social distancing.

Organisational support may also affect the homeworking experience including homeworkers' well-being (Bentley et al., 2016). This relates to traditional forms of support, in the form of technology and training, but also to the effective provision of home office devices and furnishings that play an important role in workers' physical and mental wellbeing and their productivity. Studies have suggested that the implementation of homebased working may be a key factor in the subsequent effects on employee performance and work-family conflict (Lautsch, Kossek and Eaton, 2009). Particularly for those without the means to invest in their home-office environment, organisational support may be necessary to mitigate socioeconomic differences and their impact on well-being and productivity.

Not all homebased working is driven by ICT and not all homebased work takes place via Zoom meetings. We must be attentive to how different occupations are affected by COVID-19 and associated health measures (Bapuji et al., 2020). Yet, those homebased workers who are not 
working via laptops and virtual conferencing have been strangely absent from a lot of the debates about the impacts of lockdown. This ignores the potential for significant spatial inequalities that are likely to particularly relevant to enforced homebased working (Reuschke and Felstead, 2020).

In contrast to the findings in Redman, Snape and Ashurst's (2009) study of professionals and managers highlighted above, homeworkers in manual occupations, disproportionately women and ethnic minority workers, have been found to be particularly vulnerable to exploitation. These groups are more likely to report low levels of pay, in contrast to nonmanual homeworkers who tend to be paid more than their office-based colleagues (Felstead et al., 2001). Heyes and Gray (2001) studied homebased workers in the clothing and textiles industry following the UK's introduction of a national minimum wage. Heyes and Gray highlight how, as the result of interconnected socio-economic factors, ethnic minority women are disproportionately represented among homebased workers. The researchers found evidence of improved pay as a result of the minimum wage but also noted that homebased workers were generally underpaid and reluctant to challenge their employers. Worryingly, such socio-economic differences in studies of homebased working are frequently side-lined.

\section{Conclusion}

Homebased working will be a boon to many with its potential to improve flexibility and worklife balance. However, this is far from the full story. In relation to homebased working under COVID-19 measures we must focus on the often exacting and sometimes unforgiving expectations that organisations have placed on workers, as well as providing a critical understanding of the robustness of any support systems that may have been put in place (Lautsch et al., 2009; Crain and Stevens, 2018). As we begin to prepare for an increased 
prevalence of homebased work in many of our lives, it is vital that we seek to understand this phenomenon critically and comprehensively.

\section{References}

Alon, T., Doepke, M., Olmstead-Rumsey, J. and Tertilt, M. (2020), "The Impact of COVID-19 on Gender Equality", Covid Economics: Vetted and Real time Papers, Issue 4, CEPR Press, London.

Andrew et al. (2020), How are Mothers and Fathers Balancing Work and Family Under Lockdown? IFS Briefing Note BN290, The Institute for Fiscal Studies, London.

Bailyn, L. (2006), Breaking the Mold: Redesigning Work for Productive and Satisfying Lives, Cornell University Press, Ithaca, NY.

Bapuji, H., Patel, C., Ertug, G. and Allen, D.G. (2020), "Corona crisis and inequality: Why management research needs a societal turn", Journal of Management, OnlineFirst.

Bartik, A.W., Cullen, Z.B., Glaeser, E.L., Luca, M. and Stanton, C.T. (2020), "What jobs are being done at home during the Covid-19 crisis? Evidence from firm-level surveys", NBER Working Paper No. 27422, National Bureau of Economic Research.

Beauregard, A., Basile, K. and Canoico, E. (2013), Home is Where the Work is: A New Study of Homeworking in ACAS and Beyond, ACAS Research Paper Ref 01/13, Advisory, Conciliation and Arbitration Service, London.

Bentley, T.A., Teo, S.T.T., McLeod, L., Tan, F., Bosua, R. and Gloet, M. (2016), "The role of organisational support in teleworker wellbeing: A socio-technical systems approach", Applied Ergonomics, Vol.52, pp.207-215.

Blanchflower, D.G. (2019), Not Working: Where Have All the Good Jobs Gone? Princeton University Press, Princeton.

Cable, N. and Sacker, A. (2019), "Validating overcrowding measures using the UK Household Longitudinal Study", SSM-Population Health, Vol.8, 100439.

Chung, H. and Van der Lippe, T. (2018), "Flexible working, work-life balance, and gender equality: Introduction", Social Indicators Research, pp.1-17.

Cooper, C.D. and Kurland, N.B. (2002), "Telecommuting, professional isolation, and employee development in public and private organizations", Journal of Organizational Behavior, Vol.23 No.4, pp.511-532.

Crain, T.L. and Stevens, S.C. (2018), "Family-supportive supervisor behaviors: A review and recommendations for research and practice", Journal of Organizational Behavior, Vol.39 No.7, pp.869-888. 
Dale, K. (2014), "Family and household reproduction", The Routledge Companion to Alternative Organization, M. Parker, G. Cheney, V. Fournier and C. Land (Eds.), Routledge, Abingdon, pp.144-158.

European Commission (2020), "How usual is it to work from home?" Available at: https://ec.europa.eu/eurostat/web/products-eurostat-news/-/DDN-20200424-1\# (accessed 12 June 2020.

Felstead, A., Jewson, N., Phizacklea, A. and Walters, S. (2001), "Working at home: statistical evidence for seven key hypotheses", Work, Employment and Society, Vol.15 No.2, pp.215231.

Fitzgerald, M.A. and Winter, M. (2001), "The intrusiveness of home-based work on family life", Journal of Family and Economic Issues, Vol.22 No.1, pp.75-92.

Guardian (2020a), "Covid-19 could cause permanent shift towards home working”, available at: https://www.theguardian.com/technology/2020/mar/13/covid-19-could-causepermanent-shift-towards-home-working (accessed 12 June 2020).

Guardian (2020b), "Domestic abuse surge in coronavirus lockdown could have lasting impact MPs say", available at: https://www.theguardian.com/society/2020/apr/27/domestic-abusesurge-coronavirus-lockdown-lasting-impact-mps (accessed 12 June 2020).

Guardian (2020c), "'Calamitous': domestic violence set to soar by $20 \%$ during global lockdown", available at: https://www.theguardian.com/globaldevelopment/2020/apr/28/calamitous-domestic-violence-set-to-soar-by-20-during-globallockdown-coronavirus (accessed 12 June 2020).

Halford, S. (2005), "Hybrid workspace: re-spatialisations of work, organisation and management", New Technology, Work and Employment, Vol.20 No.1, 19-33.

Heyes, J. and Gray, A. (2001), "Homeworkers and the national minimum wage: evidence from the textiles and clothing industry", Work, Employment and Society, Vol.15 No.4, pp.863-873.

Huws, U., Podro, S., Gunnarsson, E., Weijers, T., Arvanitaki, K. and Trova, V. (1996), Teleworking and Gender, Institute of Employment Studies, Brighton.

IES (2020), "IES Working at Home Wellbeing Survey", available at: https://www.employmentstudies.co.uk/resource/ies-working-home-wellbeing-survey (accessed 12 June 2020).

Lautsch, B.A., Kossek, E.E. and Eaton, S.C. (2009), "Supervisory approaches and paradoxes in managing telecommuting implementation", Human Relations Vol.62 No.6, pp.795-827.

Lefebvre, H. (1991), The Production of Space, trans D. Nicholson-Smith, Blackwell, Oxford.

Lewis, S., Gambles, R. and Rapoport, R. (2007), "The Constraints of a "Work-Life Balance" Approach: An International Perspective", International Journal of Human Resource Management, Vol.18 No.3, pp.360-73. 
Maruyama, T., Hopkinson, P.G. and James, P.W. (2009), "A multivariate analysis of work-life balance outcomes from a large-scale telework programme", New Technology, Work and Employment, Vol.24 No.1, pp.76-88.

Munro, M. and Madigan, R. (1999), "Negotiating space in the family home", At Home: An Anthology of Domestic Space, I. Cieraad (Ed.), Syracuse University Press, Syracuse, pp.107-17.

O'Neill, T.A., Hambley, L.A., Greidanus, N.S., MacDonnell, R. and Kline, T.J. (2009), “Predicting teleworker success: an exploration of personality, motivational, situational, and job characteristics", New Technology, Work and Employment, Vol.24, pp.144-162.

ONS (2020), "Coronavirus and the social impacts on Great Britain: 17 July 2020", available at: https://www.ons.gov.uk/peoplepopulationandcommunity/healthandsocialcare/healthandw ellbeing/bulletins/coronavirusandthesocialimpactsongreatbritain/17july2020 (accessed 21 July 2020).

Powell, A. and Craig, L. (2015), "Gender differences in working at home and time use patterns: Evidence from Australia”, Work, Employment and Society, Vol.29 No.4, pp.571-589.

Redman, T., Snape, E. and Ashurst, C. (2009), "Location, location, location: Does place of work really matter?" British Journal of Management, Vol.20 No.1, pp.S171-S181.

Reuschke, D. and Felstead, A. (2020), "Changing workplace geographies in the COVID-19 crisis", Dialogues in Human Geography, Vol.10 No.2, pp. 208-212.

Sullivan, C. (2000), "Space and the Intersection of Work and Family in Homeworking Households. Community", Work and the Family, Vol.3 No.2, pp.185-204.

Sullivan, C. (2003), "What's in a name? Definitions and conceptualisations of teleworking and homeworking", New Technology, Work and Employment, Vol.18 No.3, pp.158-165.

Sullivan, C. and Lewis, S. (2001), "Home-based telework, gender, and the synchronization of work and family: perspectives of teleworkers and their co-residents", Gender, Work and Organization, Vol.8 No.2, pp.123-145.

Sullivan, C. and Smithson, J. (2007), "Perspectives of homeworkers and their partners on working flexibility and gender equity", The International Journal of Human Resource Management, Vol. 18 No.3, pp.448-461.

Tietze, S. and Musson, G. (2005), "Recasting the home-work relationship: A case of mutual adjustment?", Organization Studies, Vol.26 No.9, pp.1331-1352.

Van der Lippe, T. and Lippényi, Z. (2018), "Beyond formal access: Organizational context, working from home, and work-family conflict of men and women in European workplaces", Social Indicators Research, pp.1-20.

Vitters $\varnothing$, J., Akselsen, S., Evjemo, B. et al. (2003), "Impacts of home-based telework on quality of life for employees and their partners. quantitative and qualitative results from a European survey", Journal of Happiness Studies, Vol.4, pp.201-233. 
Wapshott, R. and Mallett, O. (2012), "The spatial implications of homeworking: A Lefebvrian approach to the rewards and challenges of home-based work", Organization, Vol.19 No.1, pp.63-79. 